\title{
Antioxidant and Anti-inflammatory Effects of Hot Water and Ethanol Extracts from Endemic Plants in Indonesia
}

\author{
Jin-Woo Hwang ${ }^{1, *}$, Jae-Ho Choi ${ }^{1, *}$, Sang-Moon Kang ${ }^{2, * *}$, \\ Sung-Gyu Lee ${ }^{1, * * *}$ and Hyun Kang ${ }^{1, \dagger, * * *}$ \\ ${ }^{1}$ Department of Medical Laboratory Science, College of Health Science, \\ Dankook University, Cheonan-si, Chungnam 31116, Korea \\ ${ }^{2} R \& D$ Center, ANPEP Inc. Cheongju-si, Chungcheongbuk-do 28101, Korea
}

\begin{abstract}
The present study, antioxidant and anti-inflammatory effects were measured of 6 endemic plants in Indonesian extracted by hot water or ethanol. The Nipa Fruticans Wurmb ethanol extract (NFWE) and Orthosiphon aristatus ethanol extract (OAE) showed the highest polyphenol and flavonoid contents of 203.70 and $33.70 \mu \mathrm{g} / \mathrm{mg}$, respectively. Antioxidant activity of OAE was highest in DPPH radical scavenging activity $(77.49 \%$ at $10 \mu \mathrm{g} / \mathrm{mL})$ and $\mathrm{ABTS}^{+}$radical scavenging activity $(93.36 \%$ at $10 \mu \mathrm{g} / \mathrm{mL})$. FRAP activity was significantly higher in NFWE than other extracts. Anti-inflammatory effects of 6 endemic plants in Indonesian extracted by hot water or ethanol were examined using nitric oxide (NO) inhibition assays. In the LPS-induced BV2 cells, OAE showed the highest inhibition of NO production without toxicity. The results of this study, suggest that OAE is a potential functional raw material for antioxidant and anti-inflammatory.
\end{abstract}

Key Words: Indonesia, Plants, Antioxidant, Anti-inflammatory, Cytotoxicity

\section{서 론}

인도네시아는 세계 3 위의 열대우림 보유국으로 그 크 기만큼 다양한 생물종들이 자라나고 있으며, 그 중에 약 용식물도 다수 존재한다. 노니(Morinda citrifolia L.)는 열 대성 식물로 2,000년 전부터 발견된 약용식물로서 전통 민간 약용식물로 사용되어 왔다(Tabrah and Eveleth, 1966; Dixon et al., 1999). 노니의 과육은 페놀화합물, 유기산 및 알칼로이드를 포함하는 약 160 종의 화학물질과 다양한 비타민 무기질, 식이섬유 성분이 함유되어 있다(Heinicke, 1985; Wang and Su, 2001). 이런 노니의 성분들은 항균작용, 통증완화, 항고혈압, 항암, 항염증, 항산화, 세포 노화 방지 등 다양한 효능이 알려져 있다(Pande et al., 2005; Sunder et al., 2013; Lee et al., 2018; Lee, 2020).

모링가(Moringa oleifera)는 Moringaceae의 한 종류로, 열대지방 또는 아열대지방에서 자라며, 강수량이 적 은 환경에서도 잘 자라 전 세계적으로 재배되고 있다 (Gopalakrishnan et al., 2016). Flavonoid와 isothiocyanates, glucosinolates 등의 성분을 함유하고 있고, 단백질, 미네랄, 비타민 등의 풍부한 영양가가 높게 함유되어 있으며, 간 기능 보호에 효과가 있다(Hamza, 2009). 그 외 항염증, 항 암, 항당뇨 등 다양한 활성과 암세포의 증식 억제 효과가 있다(Sreelatha et al., 2011; Kou et al., 2018; Lin et al., 2018; Choi et al., 2021).

자바 차(Orthosiphon aristatus)는 동남아시아 전역에서 발견되는 약초로 항알레르기, 항고혈압, 항염, 이뇨 성질 등의 많은 건강 개선 특성을 가지고 있어, 신장 질환, 요

Received: July 27, 2021 / Revised: September 15, 2021 / Accepted: September 16, 2021

${ }^{*}$ Researcher, ${ }^{* *}$ Chief Technology Officer, ${ }^{* * *}$ Professor.

${ }^{\dagger}$ Corresponding author: Hyun Kang. Department of Medical Laboratory Science, College of Health Science, Dankook University, Cheonan-si, Chungnam 31116, Korea.

Tel: +82-41-550-3015, Fax:+82-41-559-7934, e-mail: hkang@dankook.ac.kr

(C) The Korean Society for Biomedical Laboratory Sciences. All rights reserved.

(c) This is an Open Access article distributed under the terms of the Creative Commons Attribution Non-Commercial License (http://creativecommons.org/licenses/by-nc/3.0/) which permits unrestricted non-commercial use, distribution, and reproduction in any medium, provided the original work is properly cited. 
로 감염, 당뇨병, 방광 결석, 혈압, 통풍 및 류마티즘 등을 치료하는데 수세기 동안 사용되어 왔다(Klungboonkrong et al., 2019). 자바 차는 높은 비율의 칼륨, 미네랄, 에센 셜 오일 및 친유성 플라본을 함유하고 있으며, 이 플라본 에는 sinensetin (SEN), flavonol glycoside, 카페인산 유도체 (rosmarinic acid, 2,3-dicaffeoly-1-tartaric acid) 이노시톨, 피토 스테롤 및 사포닌이 포함되어 있으며(Ameer, 2012), 항산 화, 항암 및 항균 효능 등을 가지고 있다(Dole`cková et al., 2012; López-Vidaña et al., 2017; Klungboonkrong et al., 2019).

그라비올라(Annona muricate)는 남미, 북미, 필리핀, 인도 네시아 등 열대지방에서 재배되는 목련목 포도나무과로, 주요 성분으로는 flavonoids, isoquinoline alkaloids, annonaceous acetogenins 등이 풍부하게 함유되어 있다(Matsushige et al., 2012; Nawwar et al., 2012; Paul et al., 2013; Thang et al., 2013; Gavamukulya et al., 2014; Sun et al., 2014). 그라비올라 는 염증, 류마티즘, 당뇨병, 고혈압, 불면증 및 기생충 감 염 등을 포함한 질병의 치료에 광범위하게 사용되어 왔 으며, 특히 주성분인 annonaceous acetogenins은 암세포의 사망을 성공적으로 유도시키는 것으로 주목받고 있다 (Adewole and Ojewole, 2009; Torres et al., 2012; Ishola et al., 2014; Moghadamtousi et al., 2014; Asare et al., 2015; Park et al., 2017).

해죽순(Nypa fruticans Wurmb)은 동남아시아 열대지방 및 아열대 지역의 해안갯벌이나 맹그로브 지대 등의 습지에 서 자라는 야자나무과 식물로서, 국내에서는 해죽순으로 불린다(Tamunaidu and Saka, 2011; Hossain and Islam, 2015; Sugai et al., 2016). 해죽순에는 다량의 폴리페놀 및 플라 보노이드 화합물이 함유되어 있어 항산화 및 염증 조절 효과가 뛰어난 것으로 보고되어 있다(Prasad et al., 2013; Yosoff et al., 2015; Bae and Park, 2016).

본 연구에서는 인도네시아의 약용식물인 노니, 모링가 잎, 자바 차, 그라비올라 잎과 분말, 해죽순의 열수 및 에 탄올 추출물의 항산화 및 항염증 기능성 소재로서의 가 능성을 검토하기 위하여 폴리페놀, 플라보노이드 함량을 확인하고 $\mathrm{DPPH}, \mathrm{ABTS}$ 억제 활성과 $\mathrm{FRAP}$ 활성을 측정하 여 항산화력을 확인하였으며, NO 생성 억제 활성을 측정 하여 항염증 소재로서의 가능성을 확인하였다.

\section{재료 및 방법}

\section{실험재료}

Folin 시약, $\mathrm{Na}_{2} \mathrm{CO}_{3}$, gallic acid, aluminium nitrate, potassium acetate, quercetin, 1,1-diphenyl-2-picryl hydrazyl (DPPH), 2,2'Azino-bis(3-ethylbenzothiazoline-6-sulfonic acid) diammonium salt (ABTS), potassium persulfate, 2,4,6-Tris(2-pyridyl)-s-triazine (TPTZ), Iron (II) sulfate heptahydrate $\left(\mathrm{FeSO}_{4}\right)$, sodium nitrate, sulfanilamide, naphthylethylendiamine, phosphoric acid, LPS, Dimethyl sulfoxide (DMSO)와 3-(4,5-Dimethylthiazol-2-yl)2,5-Diphenyltetrazol-ium Bromide (MTT)는 Sigma-Aldrich Chemical Co. (St. Louis, MO, USA)로부터 구입하여 사용하 였다. 세포배양에 사용된 시약으로 fetal bovine serum (FBS), penicillin과 RPMI 1640 배지는 Gibco BRL Co. (Grand Island, $\mathrm{NY}, \mathrm{USA}$ )에서 구입하여 사용하였다.

\section{시료의 추출물 제조}

본 연구에 사용된 6종의 인도네시아 자생식물(노니, 모링가 잎, 자바 차, 그라비올라 잎 및 분말, 해죽순)은 One-tech solution Co., Ltd (Seoul, Korea)에서 구입하였다. 인도네시아 자생식물 열수 추출물 제조는 건조된 원료에 고형분 대비 10 배수의 정제수를 첨가하여 $100^{\circ} \mathrm{C}$ 에서 30 분 간 열수 추출한 후 상온에서 26시간 추가 추출 후 여 과하여 열수 추출액을 제조하였다. 인도네시아 자생식물 $70 \%$ 에탄올 추출물 제조는 건조된 원료에 10 배수의 $70 \%$ 에탄올을 첨가하여 72 시간 동안 상온에서 추출 후 여과 하여 에탄올 추출액을 제조하였다. 열수 추출액과 에탄올 추출액은 각각 감압 농축한 다음, 동결건조기(Ilshinbiobase Co., Ltd, Yangju, Korea)를 이용하여 동결건조 후 실험에 사용하였다. 본 연구에 사용된 각 추출물의 학명 및 시료 명은 Table 1에 제시하였다.

\section{총 폴리페놀 및 플라보노이드 함량 측정}

인도네시아 원료 추출물의 총 폴리페놀 화합물의 함량 은 Folin-Denis법(Folin and Denis, 1912)을 응용하여 측정하 였다. 각 추출물을 농도별로 희석한 용액을 $50 \%$ 로 희석 된 Folin 시약을 동량 혼합한 후 혼합액을 3분간 반응시 킨다. 혼합액에 $10 \% \mathrm{Na}_{2} \mathrm{CO}_{3}$ 를 동량 혼합하고 1시간 동안 반응시킨 후 Microplate Spectrophotometer (xMARK, BIORAD Co., California, USA)를 사용하여 $700 \mathrm{~nm}$ 에서의 흡광 도를 측정하였다. 추출물의 총 폴리페놀 함량은 농도별 gallic acid를 추출물과 동일한 방법으로 측정하여 표준곡 선을 작성하여 구하였다.

추출물의 총 플라보노이드 함량은 Nieva Moreno 등 (2000)의 방법을 변형하여 측정하였다. 각 추출물을 농도 별로 희석한 시료 $100 \mu \mathrm{L}$ 와 $80 \%$ 에탄올 $860 \mu \mathrm{L}$ 을 혼합 
Table 1. Lists of Indonesia endemic plants in used in this study

\begin{tabular}{llll}
\hline \hline \multicolumn{1}{c}{ Scientific name } & Korean name & Sample name & Extraction condition \\
\hline \multirow{2}{*}{ Morinda citrifolia L. } & 노니 & MCLW & Hot water \\
& & MCLE & $70 \%$ EtOH \\
\hline \multirow{2}{*}{ Moringa oleifera Leaf } & 모링가 잎 & MOLW & Hot water \\
Orthosiphon aristatus & 자바 차 & MOLE & $70 \%$ EtOH \\
\hline \multirow{2}{*}{ Annona muricata Leaf } & 그라비올라 잎 & OAW & Hot water \\
\cline { 2 - 4 } Nipa Fruticans Wurmb & 해죽순 & AMLW & $70 \%$ EtOH \\
\hline \multirow{2}{*}{ Annona muricata Powder } & 그라비올라 분말 & AMLE & Hot water \\
\cline { 2 - 4 } & & NFWE & $70 \%$ EtOH \\
\hline
\end{tabular}

한 혼합액에 $10 \%$ aluminium nitrate $20 \mu \mathrm{L}$ 와 $1 \mathrm{M}$ potassium acetate $20 \mu \mathrm{L}$ 을 혼합하여 실온에서 40 분간 방치한 뒤 $415 \mathrm{~nm}$ 에서 흡광도를 측정하였다. 총 플라보노이드 함량 의 표준물질로는 농도별 quercetin을 동일한 방법으로 측 정하여 표준곡선을 작성하여 함량을 구하였다.

\section{$\mathrm{DPPH}$ 라디칼 소거 활성 측정}

인도네시아 원료 추출물의 자유 라디칼 소거 활성은 stable radical인 DPPH에 대한 환원력을 측정한 것으로 메 탄올에 각 농도별로 희석한 추출물의 희석액 $160 \mu \mathrm{L}$ 을 $517 \mathrm{~nm}$ 에서 초기값 측정 후 메탄올에 녹인 $0.15 \mathrm{mM} \mathrm{DPPH}$ 용액 $40 \mu \mathrm{L}$ 를 가하여 실온에 30 분 방치한 후 $517 \mathrm{~nm}$ 에서 흡광도를 측정하였다. $\mathrm{DPPH}$ 의 시료 추출물에서의 라디칼 소거 활성은 다음 식에 따라 소거 활성을 계산하였으며, 대조군으로 메탄올을 사용하였다.

$\mathrm{DPPH}$ 의 radical scavenging activity $(\%)=[100-(\mathrm{S} / \mathrm{C} \times 100)]$

$\mathrm{S}$ : 시료군 반응 후 흡광도 - 시료군 반응 전 흡광도

$\mathrm{C}$ : 대조군 반응 후 흡광도 - 대조군 반응 전 흡광도

\section{$\mathrm{ABTS}$ 라디칼 소거 활성 측정}

$\mathrm{ABTS}$ 의 radical을 이용한 항산화력 측정은 $\mathrm{ABTS}^{+\cdot}$ cation decolorization assay 방법을 응용하여 수행하였다(Re et al., 1999). $7 \mathrm{mM}$ ABTS와 $2.45 \mathrm{mM}$ potassium persulfate를 최종 농도로 동량 혼합하여 실온인 암실에서 24시간 동안 방 치하여 $\mathrm{ABTS}^{+}$을 형성시킨 후 $732 \mathrm{~nm}$ 에서 흡광도 값이 $0.70( \pm 0.02)$ 이 되게 phosphate buffered saline (PBS, $\mathrm{pH} 7.4)$
로 희석하였다. 희석된 용액 $180 \mu \mathrm{L}$ 에 추출물 $20 \mu \mathrm{L}$ 를 가 하여 정확히 1 분 동안 방치한 후 흡광도를 측정하였다.

\section{FRAP법을 사용한 총 항산화력 측정}

시료 추출물의 FRAP법을 사용한 총 항산화력 평가는 $300 \mathrm{mM}$ acetate buffer (pH 3.6), $40 \mathrm{mM} \mathrm{HCl}$ 에 녹인 $10 \mathrm{mM}$ TPTZ 및 $20 \mathrm{mM} \mathrm{FeCl} \cdot 6 \mathrm{H}_{2} \mathrm{O}$ 를 각각 $10: 1: 1(\mathrm{v} / \mathrm{v} / \mathrm{v})$ 의 비 율로 혼합하여 FRAP 시약을 제조하였다. 시료 $50 \mu \mathrm{L}$ 와 $1.0 \mathrm{~mL}$ 의 FRAP 시약을 혼합하고 $37^{\circ} \mathrm{C}$ 에서 5 분간 반응시 킨 후 $593 \mathrm{~nm}$ 에서 흡광도를 측정하였다. 결과는 $\mathrm{FeSO}_{4}$ 를 표준물질로 하여 $\mathrm{mM} \mathrm{FeSO}_{4}$ equivalent/mg extract로 표시하 였다.

\section{세포주 배양}

본 연구에는 마우스 유래 microglial cell line인 BV2를 한국세포주은행에서 분양 받아 사용하였다. 세포는 $10 \%$ FBS, $100 \mu \mathrm{g} / \mathrm{mL}$ penicillin을 첨가한 RPMI 1640 배지를 이 용하여 $5 \% \mathrm{CO}_{2}$ 가 존재하는 $37^{\circ} \mathrm{C}$ 배양기에서 $1 \sim 2$ 일에 한 번씩 배양해주었다.

\section{세포생존율 측정}

시료의 추출물을 배양 세포주인 BV2 cell에 처리한 다 음에 세포의 생존율을 확인하기 위하여 MTT 시약을 이 용하여 측정하였다. 96 well plate에 $1 \times 10^{4}$ cells/well의 세 포를 $100 \mu \mathrm{L}$ 씩 분주하여 20 시간 이상 $\mathrm{CO}_{2}$ 배양기에서 배 양 후, 무혈청 배지로 교환한 후 시료를 각 농도에 따라 
Table 2. Contents of total polyphenols and flavonoids of endemic plants in Indonesia

\begin{tabular}{lcc}
\hline \hline Sample $)^{1)}$ & $\begin{array}{c}\text { Total polyphenols } \\
(\mu \mathrm{g} \mathrm{GAE} / \mathrm{mg})\end{array}$ & $\begin{array}{c}\text { Total flavonoids } \\
\left(\mu \mathrm{Q} \mathrm{QE}^{3} / \mathrm{mg}\right)\end{array}$ \\
\hline MCLW & $45.00 \pm 2.33^{4) \mathrm{c}}$ & $16.96 \pm 0.83^{\mathrm{ab}}$ \\
MCLE & $25.73 \pm 25.31^{\mathrm{a}}$ & - \\
MOLW & $37.93 \pm 3.06^{\mathrm{b}}$ & $16.13 \pm 0.42^{\mathrm{a}}$ \\
MOLE & $60.70 \pm 6.64^{\mathrm{e}}$ & $32.63 \pm 0.43^{\mathrm{e}}$ \\
OAW & $139.23 \pm 13.20^{\mathrm{h}}$ & $23.63 \pm 2.17^{\mathrm{cd}}$ \\
OAE & $185.41 \pm 12.49^{\mathrm{ij}}$ & $33.70 \pm 1.77^{\mathrm{e}}$ \\
AMLW & $83.02 \pm 4.21^{\mathrm{f}}$ & $22.65 \pm 0.24^{\mathrm{c}}$ \\
AMLE & $111.22 \pm 11.42^{\mathrm{g}}$ & $21.13 \pm 0.00^{\mathrm{c}}$ \\
NFWW & $176.81 \pm 23.10^{\mathrm{i}}$ & $24.74 \pm 0.96^{\mathrm{d}}$ \\
NFWE & $203.70 \pm 33.25^{\mathrm{j}}$ & $23.7 \pm 0.42^{\mathrm{d}}$ \\
AMPW & $24.23 \pm 3.19^{\mathrm{a}}$ & $18.21 \pm 1.10^{\mathrm{b}}$ \\
AMPE & $50.55 \pm 2.86^{\mathrm{d}}$ & $16.63 \pm 0.21^{\mathrm{ab}}$ \\
\hline
\end{tabular}

1) Sample information is presented in Table 1

2) Total phenolic content was expressed as $\mu \mathrm{g} / \mathrm{mg}$ galic acid equivalent

3) Total flavonoid content was expressed as $\mu \mathrm{g} / \mathrm{mg}$ quercetin equivalent

4) Each value is mean \pm S.D. $(n=3)$

처리한 후 24시간 뒤에 MTT 농도가 $0.5 \mathrm{mg} / \mathrm{mL}$ 이 되도 록 첨가한 후 4시간 동안 배양하여 MTT가 환원되도록 하였다. 그 후 상등액을 제거하고 $\mathrm{DMSO}$ 를 $100 \mu \mathrm{L}$ 씩 분 주하여 formazone된 cell 결정을 용해시킨 후 Microplate Spectrophotometer (xMARK, BIO-RAD Co.)를 사용하여 $550 \mathrm{~nm}$ 에서 흡광도를 측정하였다. 세포생존율은 대조군 과 비교하여 백분율(\%)로 나타내었다.

\section{$\mathrm{NO}$ 생성 저해 효과 측정}

시료 추출물의 $\mathrm{NO}$ 생성 억제 활성을 측정하기 위한 함 량 측정은 Griess reagent를 이용하여 측정하였다. BV2 세 포를 RPMI1640 배지를 이용하여 $5 \times 10^{4} \mathrm{cells} / \mathrm{mL}$ 농도로 48 well plate에 분주하여 24시간 배양한 후, 시험 시료와 LPS $(100 \mathrm{ng} / \mathrm{mL})$ 를 함유한 배지를 동시에 처리하여 24시 간 배양하였다. 세포배양 상등액 $100 \mu \mathrm{L}$ 와 Griess 시약 ( $1 \%$ sulfanilamide, $0.1 \%$ naphthylethylendiamine in $2.5 \%$ phosphoric acid) $100 \mu \mathrm{L}$ 를 혼합하여 96 well plate에서 15 분간 반응시킨 후 Microplate Spectrophotometer (xMARK, BIO$\mathrm{RAD} \mathrm{Co}$.)를 이용하여 $540 \mathrm{~nm}$ 에서 흡광도를 측정하였으며, sodium nitrate로 표준곡선을 작성하여 $\mathrm{NO}$ 의 함량을 산출 하였다.

\section{통계학적 분석}

대조군과 추출물 처리군의 결과에 대한 통계처리는 Student's $t$-test로 비교하였으며, 통계처리 후 $P$ 값이 0.05 미만일 경우 통계적인 유의성이 있다고 판정하였다.

\section{결과 및 고찰}

\section{총 폴리페놀 화합물과 총 플라보노이드 함량}

노니, 모링가 잎, 자바 차, 그라비올라 잎, 그라비올라 분말 및 해죽순의 열수 및 에탄올 추출물에 존재하는 총 폴리페놀 함량과 플라보노이드 함량을 측정한 결과를 Table 2에 나타내었다.

폴리페놀 성분은 식물에 널리 분포되어 있는 2 차 대사 산물 중 하나로 항산화, 항균, 항암, 항당뇨 등 다양한 생 리 기능을 나타내는 물질로 잘 알려져 있다(Choi and Ohk, 2017). 각 시료의 열수 추출물 중 폴리페놀 함유량은 해 죽순 추출물이 $176.81 \mu \mathrm{g} / \mathrm{mg}$ 으로 가장 높은 함유량을 나 타내었고, 자바 차와 그라비올라 잎의 열수 추출물이 그 다음으로 많은 함량을 나타내었다.

플라보노이드는 독성을 거의 나타내지 않고 생체 내 강 한 항산화 작용으로 잘 알려져 있다(Choi and Ohk, 2017). 이 플라보노이드 함량도 해죽순 열수 추출물에서 $24.74 \mu \mathrm{g}$ $/ \mathrm{mg}$ 으로 가장 높은 함량으로 검출되었으며, 그 다음으로 자바 차와 그라비올라 잎의 열수 추출물이 높은 플라보 노이드 함량을 보여주었다(Table 2).

반면에, 에탄올 추출물에서는 해죽순 에탄올 추출물이 $203.70 \mu \mathrm{g} / \mathrm{mg}$ 으로 가장 높은 총 폴리페놀 함유량을 보여 주었고, 다음으로 자바 차와 그라비올라 잎 추출물이 높 은 총 폴리페놀 함유량을 나타내었다. 플라보노이드 함량 은 $33.70 \mu \mathrm{g} / \mathrm{mg}$ 으로 자바 차가 가장 높은 함유량으로 검 출되었고, 다음으로 모링가 잎, 해죽순 순으로 높은 총 플라보노이드 함량을 보여주었다(Table 2).

시료의 열수 및 에탄올 추출물의 총 폴리페놀 함량을 보면 노니를 제외한 나머지 시료의 에탄올 추출물에서 열수 추출물보다 높은 함량을 나타내었고, 플라보노이드 함량의 경우에는 모링가 잎과 자바 차를 제외한 나머지 시료의 열수 추출물에서 에탄올 추출물보다 높은 함유량 이 검출되었다(Table 2). 또한, Choi 등 (2021)의 연구에서 는 히비스커스 꽃잎, 모링가 겉씨, 차용 해죽순의 열수 추출물 중 차용 해죽순의 $109.04 \mu \mathrm{g} / \mathrm{mg}$ 의 폴리페놀 함량, $13.49 \mu \mathrm{g} / \mathrm{mg}$ 의 플라보노이드 함량보다 높은 함량을 함량 
Table 3. DPPH and ABTS radical scavenging activities of the extracts of endemic plants in Indonesia

\begin{tabular}{|c|c|c|c|}
\hline \multicolumn{2}{|c|}{ Sample ${ }^{1)}$} & \multicolumn{2}{|c|}{ Radical scavenging activity (\%) } \\
\hline $\begin{array}{l}\text { Sample } \\
\text { name }\end{array}$ & $\begin{array}{l}\text { Concentration } \\
(\mu \mathrm{g} / \mathrm{mL})\end{array}$ & $\begin{array}{l}\text { DPPH } \\
\text { radical }\end{array}$ & $\begin{array}{l}\text { ABTS } \\
\text { radical }\end{array}$ \\
\hline \multirow{3}{*}{ MCLW } & 10 & $0.36 \pm 1.09$ & $0.36 \pm 1.09$ \\
\hline & 50 & $18.43 \pm 2.32$ & $18.43 \pm 2.32$ \\
\hline & 100 & $40.51 \pm 6.03$ & $40.51 \pm 6.03$ \\
\hline \multirow{3}{*}{ MCLE } & 10 & - & $45.73 \pm 12.71$ \\
\hline & 50 & - & $93.24 \pm 0.10$ \\
\hline & 100 & $6.37 \pm 11.25$ & $93.31 \pm 0.14$ \\
\hline \multirow{3}{*}{ MOLW } & 10 & $5.11 \pm 1.67$ & $5.11 \pm 1.67$ \\
\hline & 50 & $27.01 \pm 1.67$ & $27.01 \pm 1.67$ \\
\hline & 100 & $46.72 \pm 6.42$ & $46.72 \pm 6.42$ \\
\hline \multirow{3}{*}{ MOLE } & 10 & - & $69.16 \pm 1.01$ \\
\hline & 50 & $28.46 \pm 0.65$ & $92.57 \pm 0.08$ \\
\hline & 100 & $85.39 \pm 1.12$ & $92.48 \pm 0.00$ \\
\hline \multirow{3}{*}{ OAW } & 10 & $69.92 \pm 1.41$ & $69.92 \pm 1.41$ \\
\hline & 50 & $90.24 \pm 0.00$ & $90.24 \pm 0.00$ \\
\hline & 100 & $92.28 \pm 0.70$ & $92.28 \pm 0.70$ \\
\hline \multirow{3}{*}{$\mathrm{OAE}$} & 10 & $77.49 \pm 1.09$ & $93.36 \pm 0.08$ \\
\hline & 50 & $94.79 \pm 0.82$ & $93.27 \pm 0.08$ \\
\hline & 100 & $95.26 \pm 0.41$ & $93.13 \pm 0.08$ \\
\hline \multirow{3}{*}{ AMLW } & 10 & $14.38 \pm 1.37$ & $14.38 \pm 1.37$ \\
\hline & 50 & $90.87 \pm 2.41$ & $90.87 \pm 2.41$ \\
\hline & 100 & $99.77 \pm 1.43$ & $99.77 \pm 1.43$ \\
\hline \multirow{3}{*}{ AMLE } & 10 & $27.85 \pm 0.40$ & $92.89 \pm 0.00$ \\
\hline & 50 & $92.69 \pm 0.40$ & $93.31 \pm 0.20$ \\
\hline & 100 & $94.06 \pm 0.40$ & $93.40 \pm 0.08$ \\
\hline \multirow{3}{*}{ NFWW } & 10 & $45.21 \pm 0.68$ & $45.21 \pm 0.68$ \\
\hline & 50 & $97.03 \pm 0.40$ & $97.03 \pm 0.40$ \\
\hline & 100 & $106.39 \pm 12.26$ & $106.39 \pm 12.26$ \\
\hline \multirow{3}{*}{ NFWE } & 10 & $67.35 \pm 1.98$ & $93.31 \pm 0.00$ \\
\hline & 50 & $94.52 \pm 0.0$ & $93.27 \pm 0.08$ \\
\hline & 100 & $94.75 \pm 0.40$ & $92.89 \pm 0.14$ \\
\hline \multirow{3}{*}{ AMPW } & 10 & $2.97 \pm 2.09$ & $2.97 \pm 2.09$ \\
\hline & 50 & $20.78 \pm 1.05$ & $20.78 \pm 1.05$ \\
\hline & 100 & $42.01 \pm 1.05$ & $42.01 \pm 1.05$ \\
\hline \multirow{3}{*}{ AMPE } & 10 & $2.74 \pm 1.19$ & $87.88 \pm 0.64$ \\
\hline & 50 & $14.16 \pm 1.05$ & $90.76 \pm 0.16$ \\
\hline & 100 & $27.63 \pm 2.09$ & $85.28 \pm 0.08$ \\
\hline
\end{tabular}

${ }^{1)}$ Sample information is presented in Table 1

을 보여주었다. 본 연구에서 높은 폴리페놀과 플라보노이 드 함량을 보여준 추출물은 $\mathrm{Ku}$ 등 (2009)의 옥수수 수염
의 $60 \%$ 메탄올 추출물의 $32.74 \mu \mathrm{g} / \mathrm{mg}$ 의 폴리페놀 함량과 $24.20 \mu \mathrm{g} / \mathrm{mg}$ 의 플라보노이드 함량보다 5 6배의 폴리페놀 함량을 보여주었다.

결론적으로 총 폴리페놀 함량은 $203.70 \mu \mathrm{g} / \mathrm{mg}$ 으로 해죽 순 에탄올 추출물이, 총 플라보노이드는 $33.70 \mu \mathrm{g} / \mathrm{mg}$ 으로 자바 차 에탄올 추출물이 가장 높은 함유량을 보여주었다.

\section{라디칼 소거 활성}

시료의 항산화 활성은 DPPH 및 $\mathrm{ABTS}$ 라디칼 소거 활 성을 통하여 확인하였다. 각 농도별 DPPH 라디칼 저해능 을 백분율로 나타낸 결과를 Table 3에 나타내었다. DPPH 라디칼은 비교적 안정한 라디칼로, 정색성을 잃게 되는 성질을 이용하여 항산화능의 정도를 측정할 수 있다(Lee and Cho, 2016). 각 시료 추출물의 DPPH 라디칼 소거능 을 확인해 보면 자바 차, 그라비올라 잎 및 해죽순의 열 수와 에탄올 추출물에서 높은 DPPH 라디칼 소거능을 나 타내었고 각 시료 $10 \mu \mathrm{g} / \mathrm{mL}$ 의 결과를 비교해 보면 자바 차 에탄올 추출물이 $77.49 \%$ 의 높은 DPPH 라디칼 소거능 을 보여주었다. ABTS를 이용한 항산화능의 측정은 potassium persulfate 반응으로 인해 생성된 ABTS 라디칼이 시 료 내의 항산화 물질에 의해 제거되어 라디칼 특유의 색 인 청록색이 탈색되는 것을 이용한 방법이다. 시료 추출 물의 ABTS 라디칼 소거능은 얼음설탕 추출물을 제외한 모든 시료 추출물에서 높은 $\mathrm{ABTS}$ 라디칼 소거능을 보 여주었으며, 특히 자바 차, 그라비올라 잎 및 해죽순의 열수와 에탄올 추출물 $10 \mu \mathrm{g} / \mathrm{mL}$ 에서 $90 \%$ 이상의 뛰어난 ABTS 라디칼 소거능을 확인할 수 있었다(Table 3). Choi 등 (2009)의 연구에서는 산수유, 복분자, 음양곽, 우슬, 현 삼, 지황 등 생약 추출물이 $90 \%$ 이상의 $\mathrm{ABTS}$ 라디칼 소 거 활성을 나타내는 농도가 $50 \mathrm{mg} / \mathrm{mL}$ 로 보고된 결과를 비교하였을 때, 자바 차, 그라비올라 잎, 해죽순 추출물의 $\mathrm{ABTS}$ 라디칼 소거 활성은 뛰어나다고 할 수 있다. 또한, 같은 농도에서 $\mathrm{DPPH}$ 라디칼보다 $\mathrm{ABTS}$ 라디칼에서 높은 라디칼 소거 활성을 나타내는 것은 라디칼을 소거하는 기작이 다르고, 기질이 결합하는 정도가 다르다는 점에서 같은 농도에서도 다른 활성을 나타내는 것으로 판단된다 (Kwon and Youn, 2014). Kim 등 (2011)의 왕쥐똥나무 잎 추 출물을 사용한 $\mathrm{DPPH}$ 라디칼 소거 활성 연구 결과를 보 면 열수 추출물의 경우 $20 \mu \mathrm{g} / \mathrm{mL}$ 에서, 에탄올 추출물의 경우 $10 \mu \mathrm{g} / \mathrm{mL}$ 에서 $50 \%$ 의 억제 활성을 보여주지만 본 연 구의 자바 차 열수, 에탄올 추출물은 $10 \mu \mathrm{g} / \mathrm{mL}$ 에서 각각 $69.92,77.49 \%$ 로 왕쥐똥나무 잎 추출물보다 높은 $\mathrm{DPPH}$ 

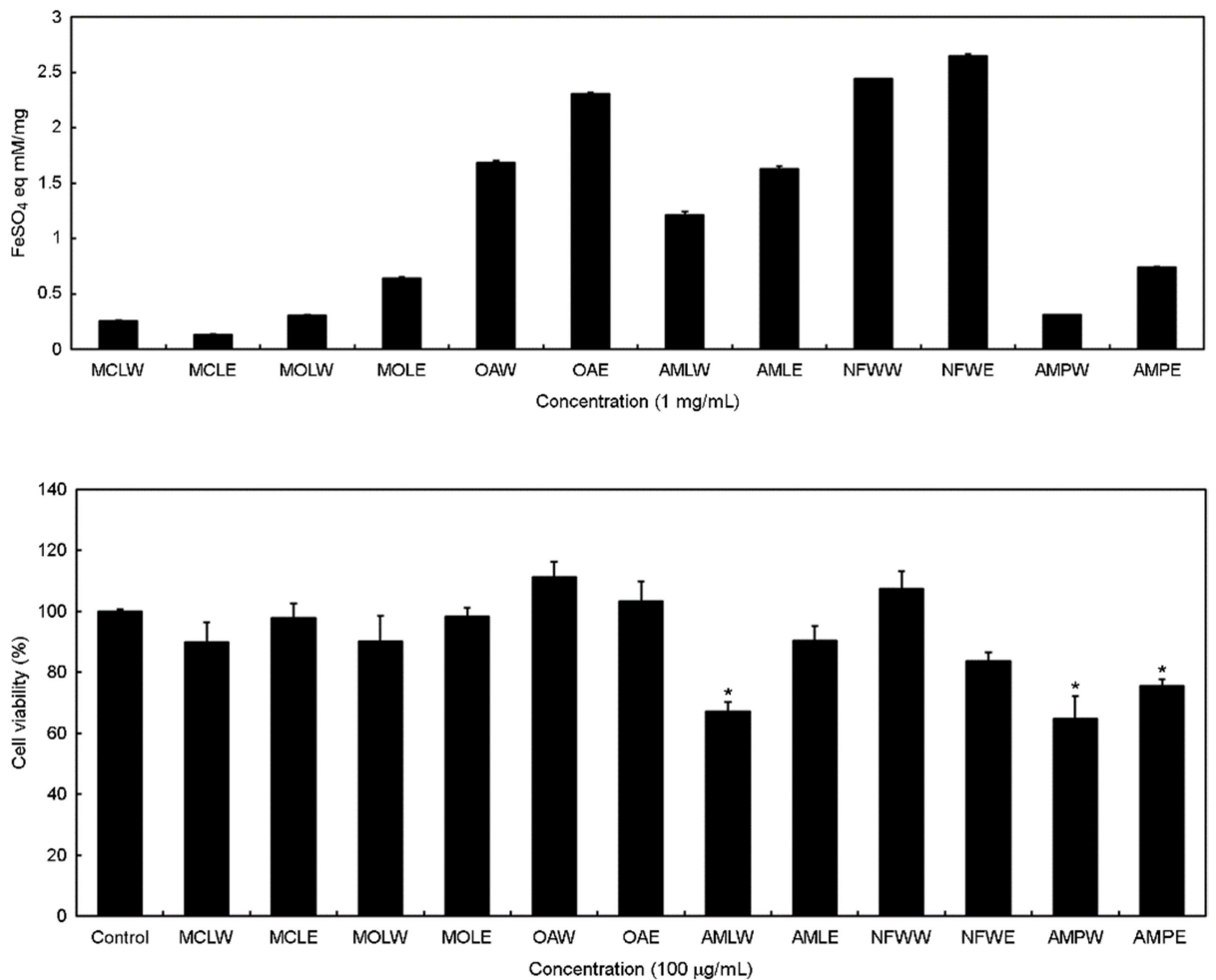

Fig. 1. FRAP activity of the extracts of endemic plants in Indonesia. Sample information is presented in Table 1. The activity of each sample was measured using a spectrophotometer. Data are means $\pm S D(n=3)$ of three replicates.

Fig. 2. Effect of the extracts of endemic plants in Indonesia on cell viability of BV2 microglia cell. Sample information is presented in table 1. Data are means $\pm \mathrm{SD}(\mathrm{n}=3)$ of three replicates. $* P<0.05$ compared to control.
라디칼 억제 활성을 나타내었다.

\section{FRAP 활성}

항산화력을 평가하는 방법 중 하나인 FRAP법은 시료 가 3 가철을 2 가철로 환원시킬 때 2 가철이 나타내는 흡광 도치를 측정하여 항산화 능력을 평가하는 방법으로 라디 칼의 소거 활성을 측정하는 $\mathrm{DPPH}, \mathrm{ABTS}$ 법과는 다른 메 커니즘의 항산화능 측정 방법이다 $(\mathrm{Ku}$ et al., 2009). 추출물 의 FRAP 활성을 확인한 결과 자바 차, 그라비올라 잎, 해죽순 추출물에서 높은 FRAP 활성을 나타내었으며, 열 수 추출물보다 에탄올 추출물에서 더 높은 FRAP 활성을 확인할 수 있었다. 특히, 해죽순 에탄올 추출물에서 2.647 $\mathrm{FeSO}_{4}$ eq. $\mathrm{mM} / \mathrm{mg}$ 으로 가장 뛰어난 $\mathrm{FRAP}$ 활성을 나타내 었다(Fig. 1). Kim 등 (2011)의 돼지감자 잎 추출물의 FRAP 활성 연구 결과를 보면 열수 및 에탄올 추출물 각각의 FRAP 활성은 0.908 과 $0.712 \mathrm{mM} \mathrm{FeSO}_{4}$ equivalent/mg extract 로 나타났으며, 본 연구의 자바 차, 그라비올라 잎, 해죽순 의 열수 및 에탄올 추출물에서 $1 \mathrm{mM} \mathrm{FeSO}_{4}$ equivalent/mg extract 이상의 FRAP 활성을 보여주어 자바차, 그라비올 라 잎, 해죽순 추출물이 높은 FRAP 활성을 가지고 있다 것이 확인되었다.

폴리페놀과 플라보노이드의 함량은 항산화 활성과 높
은 상관관계를 나타내는 것으로 잘 알려져 있다. 본 연구 에서 $\mathrm{DPPH}, \mathrm{ABTS}$ 라디칼 소거 및 FRAP 활성에서 높은 항산화 활성을 보여준 자바 차, 그라비올라 잎 및 해죽순 추출물의 이러한 결과는 폴리페놀 및 플라보노이드의 높 은 함량과 관련성이 있을 것으로 판단된다.

\section{세포생존율}

시료의 열수 및 에탄올 추출물의 세포독성을 확인하기 위하여 BV2 세포에서의 세포생존율 측정을 수행하였다 (Fig. 2). MTT assay를 활용하여 BV2 세포에서 생존율을 확인한 결과, 그라비올라 분말의 열수 및 에탄올 추출물 과 그라비올라 잎의 열수 추출물 $100 \mu \mathrm{g} / \mathrm{mL}$ 에서 세포생 존율이 $80 \%$ 미만으로 유의적인 독성을 확인할 수 있었 고, 나머지 추출물에서는 세포독성이 없음을 확인하였다.

\section{인도네시아 자생식물 추출물의 NO 생성 억제 활성 측정}

염증 반응이란 외부 자극이나 다양한 유해인자에 저항 하기 위한 일련의 생체 방어 기전이다. 그러나, 과도한 염 증 반응은 세포 손상 등의 병리적 상태에 이르게 하기 때문에 염증 반응을 유발하는 싸이토카인이나 염증 매개 체들을 조절하는 것이 염증성 질환의 치료법으로 제시 되고 있다(Zamora et al., 2000). 염증 반응을 유발하는 염 


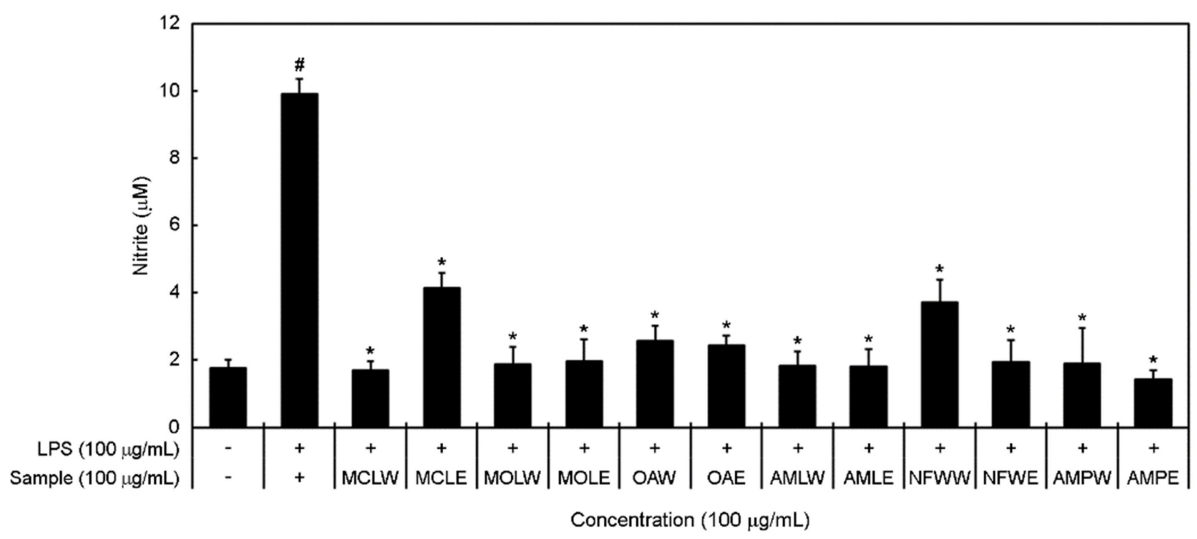

Fig. 3. Effect of the extracts of endemic plants in Indonesia on NO production in BV2 microglia cell stimulated by LPS. Sample information is presented in Table 1. Data are means $\pm S D(n=3)$ of three replicates. $\# P<0.05$ compared to LPS-untreated group; $* P<0.05$ compared to LPS-treated group.
증 매개체 중 하나인 $\mathrm{NO}$ 가 지속적이고 과도하게 생성될 경우 해당 조직에서 염증성 손상을 유발하며, 이 물질은 iNOS에 의하여 L-arginine으로부터 생성되는 것으로 알려 져 있다(Hou et al., 1999; Kang, 2018). 시료 추출물의 항염 증 활성을 확인하기 위하여 염증 반응 유발 물질인 $\mathrm{NO}$ 의 생성량을 NO assay를 수행하여 확인하였다(Fig. 3). 인 도네이시아 자생식물 추출물은 모든 군에서 $\mathrm{NO}$ 생성이 LPS 단독 처리군에 비해 유의적으로 감소하는 것을 확인 하였다. 노니 에탄올 추출물, 해죽순 열수 추출물을 제외 한 모든 추출물은 LPS 무처리 군과 유사한 NO 함량을 보였으며, 세포독성이 있는 그라비올라 잎 열수 추출물, 그라비올라 열수 및 에탄올 추출물을 제외한 모든 추출 물은 추후 항염증 소재로의 활용 가능성이 높다고 할 수 있다.

다양한 인도네시아 자생식물의 기능성 연구는 항균 활 성을 비교한 $\mathrm{Kim}$ 등 (2000)의 연구가 있으며, 본 연구는 기존 연구와 달리 인도네시아 자생식물인 노니, 모링가 잎, 자바 차, 그라비올라 잎, 그라비올라 분말, 해죽순 6종을 가지고 열수 및 에탄올 추출물을 제조하고 항산화 및 항 염증 활성을 비교하여 그 결과를 확인하였다. 인도네시아 시료 6종의 열수 및 에탄올 추출물의 항산화 활성 및 세 포독성, $\mathrm{NO}$ 생성 억제 활성을 측정한 결과 전체적으로 자 바 차 에탄올 추출물이 뛰어난 활성을 보여주었다. 12 종 의 열수 및 에탄올 추출물 중 자바 차 에탄올 추출물이 $185.41 \mathrm{mg} / \mathrm{g}$ 으로 해죽순 에탄올 추출물 다음으로 높은 폴 리페놀 함량을 보여주었으며, $33.70 \mathrm{mg} / \mathrm{g}$ 로 가장 높은 플 라보노이드 함량을 나타내었다. 자바 차 에탄올 추출물은 $\mathrm{DPPH}$ 와 $\mathrm{ABTS}$ 라디칼 소거 활성 측정에서도 $10 \mu \mathrm{g} / \mathrm{mL}$ 에 서 각각 77.49 와 $93.36 \%$ 로 가장 뛰어난 소거 활성을 보여 주었고, 해죽순 추출물 다음으로 높은 FRAP 활성을 보
여주었다. 세포독성 확인 결과 자바 차 에탄올 추출물은 $\mathrm{BV} 2$ 세포에서 세포독성을 나타내지 않았으며, BV2 세포 에서 수행한 NO 생성 억제 효능 평가에서도 $75.5 \%$ 의 억 제 효능을 보여주어 세포독성을 나타내지 않는 시료 중 가장 뛰어난 효능을 보여주었다.

결론적으로, 자바 차의 에탄올 추출물이 높은 폴리페놀 과 플라보노이드 함량과 뛰어난 $\mathrm{DPPH}, \mathrm{ABTS}$ 라디칼 소 거 활성과 FRAP 활성으로 인도네시아 원료 6종의 추출 물 중 가장 뛰어난 항산화 활성을 보여주었으며, BV2 세 포에서 세포독성을 나타내지 않는 추출물 중 가장 높은 $\mathrm{NO}$ 생성 억제 효능을 보여주었다. 자바 차 에탄올 추출 물에 대한 추가적인 연구가 진행된다면 기능성 소재로서 의 활용성을 더 높일 수 있을 것으로 판단된다.

\section{ACKNOWLEDGEMENT}

This research was supported by a grant of the Korea Health Technology R\&D Project through the Korea Health Industry Development Institute (KHIDI), funded by the Ministry of Health \& Welfare, Republic of Korea (grant number: HP20C0194).

\section{CONFLICT OF INTEREST}

The authors declare that they have no conflict of interest.

\section{REFERENCES}

Adewole S, Ojewole J. Protective effects of Annona muricata Linn. (Annonaceae) leaf aqueous extract on serum lipid profiles and oxidative stress in hepatocytes of streptozotocintreated diabetic rats. Afr J Tradit Complement Altern Med. 2009. 6: 30-41. 
Ameer OZ. Orthosiphon stamineus: traditional uses, phytochemistry, pharmacology, and toxicology: a review. J Med Food. 2012. 15: 678-690.

Asare GA, Afriyie D, Ngala RA, et al. Antiproliferative activity of aqueous leaf extract of Annona muricata L. on the prostate, BPH-1 cells, and some target genes. Integr Cancer Ther. 2015. 14: $65-74$

Bae GS, Park SJ. The Anti-inflammatory Effect of Nypa fruticans Wurmb. Fruit on Lipopolysaccharide-induced Inflammatory response on RAW 264.7 cells. Kor J Herbol. 2016. 31: 79-84.

Choi JH, Hwang JW, Lee SG, Heo SH, Kang H. Antioxidant Effect of Hot Water Extracts from 3 Types Indonesia Plants (Hibiscus Petals, Moringa oleifera Gymnosperm, and Nipa Fruticans Wurmb). J Naturopath. 2021. 10: 42-47.

Choi JH, Ohk SH. Evaluations on Antioxidant Effect of Water Extract from Graviola Leaves. J Korea Academia-Industrial cooperation Society. 2017. 18: 129-135.

Choi SS, Yim DS, Lee SK. Radical scavenging activities and protective effects against oxidative damage to DNA of extracts from medicinal plants with known osteoprotective effects. Korean J Pharmacogn, 2009. 40: 143-149.

Dixon AR, McMillen H, Etkin NL. Ferment this: The transformation of noni, a traditional Polynesian medicine (Morinda citrifolia, Rubiaceae). Econ Bot. 1999. 53: 51-68.

Dolecková I, Rárová L, Grúz J, Vondrusová M, Strnad M, Kryštof V. Antiproliferative and antiangiogenic effects of flavone eupatorin, an active constituent of chloroform extract of Orthosiphon stamineus leaves. Fitoterapia. 2012. 83: 10001007.

Folin O, Denis W. On phosphotungstic-phosphomolybdic compounds as color reagents. J Biol Chem. 1912. 12: 239-243.

Gavamukulya Y, Abou-Elella F, Wamunyokoli F, AEl-Shemy H. Phytochemical screening, anti-oxidant activity and in vitro anticancer potential of ethanolic and water leaves extracts of Annona muricata (Graviola). Asian Pac J Trop Med. 2014. 7: 355-363.

Gopalakrishnan L, Doriya K, Kumar DS. Moringa oleifera: A review on nutritive importance and its medicinal application. Food Sci Human Wellness. 2016. 5: 49-56.

Hamza AA. Ameliorative effects of Moringa oleifera Lam seed extract on liver fibrosis in rats. Food Chem Toxicol. 2009. 48: 345-355.

Heinicke RM. The pharmacologically active ingredient of noni. Pac Trop Bot Gard Bull. 1985. 15: 10-14.

Hossain F, Islam A. Utilization of mangrove forest plant: Nipa palm
(Nypa fruticans Wurmb.). Am J Agri Forest. 2015. 3: 156-160.

Hou YC, Janczuk A, Wang PG. Current trends in the development of nitric oxide donors. Curr Pharm Des. 1999. 5: 417-441.

Ishola IO, Awodele O, Olusayero AM, Ochieng CO. Mechanisms of analgesic and anti-inflammatory properties of Annona muricata Linn. (Annonaceae) fruit extract in rodents. J Med Food. 2014. 17: 1375-1382.

Kang H. Anti-Oxidative and Anti-Neuroinflammatory Effect of Ethanol Extracts from Walnuts's (Juglans regia L.) Shell. Biomedical Science Letters. 2018. 24: 365-371.

Kim MS, Lee DC, Hong JE, et al. Antimicrobial Effects of Ethanol Extracts from Korean and Indonesian plants. Korean J Food Sci Technol. 2000. 32: 949-958.

Kim YS, Lee SJ, Hwang JW, Kim EH, Park PJ, Jeon BT. Antioxidant Activity and Protective Effects of Extracts from Helianthus tuberosus L. Leaves on $t$-BHP Induced Oxidative Stress in Chang Cell. J Korean Soc Food Sci Nutr. 2011. 40: 1525-1531.

Kim YS, Lee SJ, Hwang JW, Kim EH, Park PJ, Jeong JH. Antioxidant Activities of Extracts from Ligustrum ovalifolium H. Leaves. J Korean Soc Food Sci Nutr. 2011. 40: 1642-1647.

Klungboonkrong V, Lamsal BP, Phoungchandang S. Changes and degradation kinetics of some bioactive compounds in dried Orthosiphon aristatus (Java tea) leaves during elevated temperature storage. J Sci Food Agric. 2019. 99: 933-940.

Kou X, Li B, Olayanju JB, Drake JM, Chen N. Nutraceutical or pharmacological potential of Moringa oleifera Lam. Nutrients. 2018. 10: 1-12.

$\mathrm{Ku}$ KM, Kim SK, Kang YH. Antioxidant Activity and Functional Components of Corn Silk (Zea mays L.). Korean J Plant Res. 2009. 22: 323-329.

Kwon YR, Youn KS. Antioxidant activity and physiological properties of Moringa (Moringa oleifera Lam.) leaves extracts with different solvents. Korean J Food Preserv. 2014. 21: 831837.

Lee GW, Cho YH. Antioxidant Activity of Leaf Extract from Annona muricata. Review of Korea Contents Association. 2016. 14: 43-46.

Lee KW, Je H, Jung TH, et al. Comparison of components and antioxidant activity of cherry, aronia, and maquiberry. Korean J Food Nutr. 2018. 31: 729-736.

Lee YR. Antioxidant and $\alpha$-Amylase Inhibitory Activity of $70 \%$ Ethanolic Extract from Morinda citrifolia L. (Noni). Korean J Food Nutr. 2020. 33: 210-214.

Lin M, Zhang J, Chen X. Bioactive flavonoids in Moringa oleifera 
and their health-promoting properties. J Funct Foods. 2018. 47: 469-479.

López-Vidaña EC, Figueroa IP, Cortés FB, Rojano BA, Ocaña AN. Effect of temperature on antioxidant capacity during drying process of mortiño (Vaccinium meridionale Swartz). Int J Food Prop. 2017. 20: 294-305.

Matsushige A, Kotake Y, Matsunami K, Otsuka H, Ohta S, Takeda Y. Annonamine, a new aporphine alkaloid from the leaves of Annona muricata. Chem Pharm Bull (Tokyo). 2012. 60: 257259.

Moghadamtousi SZ, Karimian H, Rouhollahi E, Paydar M, Fadaeinasab M, Kadir HA. Annona muricata leaves induce G1 cell cycle arrest and apoptosis through mitochondriamediated pathway in human HCT-116 and HT-29 colon cancer cells. J Ethnopharmacol. 2014. 156: 277-289.

Nawwar M, Ayoub N, Hussein S, et al. A flavonol triglycoside and investigation of the antioxidant and cell stimulating activities of Annona muricata Linn. Arch Pharm Res. 2012. 35: 761-767.

Nieva Moreno MI, Isla MI, Sampietro AR, et al. Comparison of the free radical-scavenging activity of propolis from several regions of Argentina. J Ethnopharmacol. 2000. 71: 109-114

Pande M, Naiker M, Mills G, Singh N, Voro T. The Kura files: Qualitative social survey. Pac Health Surveill Response. 2005. 12: 85-93.

Park SH, Kim JM, Kim JH, et al. Antioxidative Effects and Component Analysis of Graviola (Annona muricata) Leaf Extract/Fractions. J Soc Cosmet Sci Korea. 2017. 43: 309-320.

Paul J, Gnanam R, Jayadeepa RM, Arul L. Anti-cancer activity on Graviola, an exciting medicinal plant extract vs various cancer cell lines and a detailed computational study on its potent anti-cancerous leads. Curr Top Med Chem. 2013. 13: 16661673.

Prasad N, Yang B, Kong KW, et al. Phytochemicals and antioxidant capacity from Nypa fruticans Wurmb. Fruit. Evid Based Complement Alternat Med. 2013. 2013: 1-9.

Re R, Pellegrini N, Proteggente A, et al. Antioxidant activity applying an improved ABTS radical cation decolorization assay. Free Radic Biol Med. 1999. 26: 1231-1237.

Sreelatha S, Jeyachitra A, Padma PR. Antiproliferation and induction of apoptosis by Moringa oleifera leaf extract on human cancer cells. Food Chem Toxicol. 2011. 49: 1270-1275.
Sugai K, Watanabe S, Kuishi T, et al. Extremely low genetic diversity of the northern limit populations of Nypa fruticans (Arecaceae) on Iriomote Island. Japan Conserv Genet Resour. 2016. 17: 221-228.

Sun S, Liu J, Kadouh H, Sun X, Zhou K. Three new antiproliferative Annonaceous acetogenins with mono-tetrahydrofuran ring from graviola fruit (Annona muricata). Bioorg Med Chem Lett. 2014. 24: 2773-2776.

Sunder J, Jeyakumar S, Sujatha T, Kundu A. Effect of feeding of morical: A herbal based supplement on production and egg quality in Japanese quail. Adv Anim Vet Sci. 2013. 1: 157-160.

Tabrah FL, Eveleth BM. Evaluation of the effectiveness of ancient Hawaiian medicine. Hawaii Med J. 1966. 25: 223-230.

Tamunaidu P, Saka S. Chemical characterization of various parts of nipa palm (Nypa fruticans). Ind Crop Prod. 2011. 34: 14231428

Thang TD, Dai DN, Hoi TM, Ogunwande IA. Study on the volatile oil contents of Annona glabra L., Annona squamosa L., Annona muricata L. and Annona reticulata L., from Vietnam. Nat Prod Res. 2013. 27: 1232-1236.

Torres MP, Rachagani S, Purohit V, et al. Graviola: a novel promising natural-derived drug that inhibits tumorigenicity and metastasis of pancreatic cancer cells in vitro and in vivo through altering cell metabolism, Cancer Lett. 2012. 323: 29 40.

Wang MY, Su C. Cancer preventive effect of Morinda citrifolia (noni). Ann NY Acad Sci. 2001. 952: 161-168.

Yosoff NA, Ahmad M, AI-Hindi B, Widyawati T, Yam MF, Mahmud R. Aqueous extract of Nypa fruticans Wurmb. Vinegar alleviates postprandial hyperglycemia in normoglycemic rats. Nutrients. 2015. 7: 7012-7026.

Zamora R, Vodovotz Y, Billiar TR. Inducible nitric oxide synthase and inflammatory diseases. Mol Med. 2000. 6: 347-373.

https://doi.org/10.15616/BSL.2021.27.3.161

Cite this article as: Hwang JW, Choi JH, Kang SM, Lee SG, Kang H. Antioxidant and Anti-inflammatory Effects of Hot Water and Ethanol Extracts from Endemic Plants in Indonesia. Biomedical Science Letters. 2021. 27: 161-169. 